\title{
М.І. Шкільна
}

\section{ЕТІОЛОГІЧНА СТРУКТУРА ГОСТРОГО ЛАЙМ-БОРЕЛІОЗУ ЗА ВИДАМИ ЗБУДНИКА}

\author{
Тернопільський державний медичний університет ім. І.Я. Горбачевського
}

\begin{abstract}
Мета дослідження - встановити частоту інфрікування різними видами борелій пацієнтів із гострою фрормою Лайм-бореліозу (мігруючою еритемою та Лайм-артритом) в Тернопільській області.

Пацієнти і методи. Під спостереженням було 48 пацієнтів з гострою формою хвороби Лайма у віці від 19 до 65 років, які в 2018 р. перебували на амбулаторному та стаціонарному лікуванні в Тернопільському обласному клінічному шкірно-венерологічному диспансері та Університетській лікарні; серед них 19 (39,6 \%) чоловіків і 29 (60,4 \%) жінок. Пацієнтів поділили на дві групи: 34 (I група) - хворі на мігруючу еритему (ME) ma 14 (II група) - на Лайм-артрит (ЛА). Діагноз Лаймбореліозу підтверджували анамнестично, клінічно та серологічно. Специфрічний діагноз встановлювали за наявності в сироватці крові пацієнтів специфрічних IgM i (або) IgG до комплексу B. burgdorferi sencu lato (s. I.) методом ELISA та лише IgM, за допомогою реакції імунного блотингу (EUROLINE Borrelia RN-AT adv.).
\end{abstract}

Результати. Позитивні або проміжні результати серологічного дослідження сироваток крові на наявність специорічних IgM i IgG до комплексу B. burgdorferi s. I. (B. burgdorferi sensu stricto (s. S.), B. garinii, B. afzelii) за допомогою тесту ELISA (хоча б одного класу антитіл) знайдено в 24 (70,6 \%) із 34 пацієнтів з мігруючою еритемою та 11 (78,6 \%) з Лайм-артритом. Порівняння частоти діагностики специфрічних антитіл IgM (позитивних і проміжних) до B. burgdorferi s. I. (B. burgdorferi s. S., B. garinii, B. afzelii ma B. spielmanii) у 34 пацієнтів з мігруючою еритемою, методом IФA - та імуноблоту, показало, що вона була вища при використанні імуноблоту: 76,5 \% порівняно із методом IФA 55,9 \% (p<0,05). Вивчення етіологічної структури гострого Лайм-бореліозу в 26 пацієнтів з мігруючою еритемою (I група) та 12 - із Лайм-артритом (II група) встановило, що OspC B. spielmanii знайдено у 24 (92,3 \%) пацієнтів I групи та 12 (100 \%) пацієнтів з II.

Висновки. Специфрічні IgG у тесті ELISA було виявлено лише в сироватці крові 35,3 \% пацієнтів з мігруючою еритемою, що може свідчити про імунну пам'ять або хронічний процес. Гуморальну відповідь на поверхневий антиген (OspC) B. spielmanii встановлено в 92,3 \% пацієнтів з мігруючими еритемами та всіх хворих із гострим Лайм-артритом.

Ключові слова: Лайм-бореліоз, мігруюча еритема, Лайм-артрum. Borrelia burgdorferi, Borrelia spielmanii, діагностика, ІФА, імуноблот

Хвороба Лайма (кліщовий бореліоз, Лайм-бореліоз, ЛБ) - природно-вогнищевий зооноз, спричинений бореліями комплексу Borrelia s. І., які передаються людині трансмісивним шляхом при присмоктуванні іксодового кліща [1].

Збудник ЛБ - Borrelia burgdorferi - грамнегативна рухома спірохета з родини Spirochaetaceae, роду Borrelia. За відмінностями в нуклеотидній ДНК на сьогодні визначають 20 генотипів збудника, які належать до комплексу B. burgdorferi s. l., 9 з яких реєструються в Європі. Патогенними для людини вважають B. burgdorferi s. s. у Північній Америці, тоді як у Європі, окрім нього, - B. garinii, B. afzelii, B. spielmanii та B. bavariensis $[2,3,4]$.

Західний регіон країни, в тому числі й Тернопільська область, $є$ ендемічним осередком ЛБ. У цьому регіоні України патогенними для людини є такі види Borrelia: B. burgdorferi s. S., B. garinii, B. afzelii, а також B. Iusitaniae $i$ B. valaisiana $[5,6]$.

Метою роботи було встановити частоту інфікування різними видами борелій пацієнтів із гострою фрормою хвороби Лайма (мігруючою еритемою та Лайм-артритом) в Тернопільській області.

\section{Пацієнти і методи}

Під спостереженням було 48 пацієнтів з гострою формою хвороби Лайма у віці від 19 до 65 років, які в 2018 р. перебували на амбулаторному та стаціонарному лікуванні в Тернопільському обласному клінічному шкірно-венерологічному диспансері та Університетській лікарні; серед них 19 (39,6 \%) чоловіків і 29 (60,4 \%) жінок. Вікова структура пацієнтів така: 19 років - 1 хворий; 20-29 років -6; 
30-39 років - 12; 40-49 років - 10; 50-59 років - 13; 60 років і більше -6 хворих. Пацієнтів поділили на дві групи: 34 (I група) - хворі на ME та 14 (II група) - на ЛА. Діагноз ЛБ підтверджували анамнестично, клінічно та серологічно. Специфрічний діагноз встановлювали за наявності в сироватці крові пацієнтів специфічних IgM і (або) IgG до комплексу B. burgdorferi s. I. методом ELISA та лише IgM за допомогою реакції імунного блотингу.

Для визначення специсрічних антитіл до комплексу B. burgdorferi s. I. (B. burgdorferi s. S., B. garinii, B. afzelii) використовували тест-системи компанії Euroimmun AG
(Німеччина), зокрема тест-систему anti-Borrelia burgdorferi ELISA (IgM), тa anti-Borrelia plus VIsE ELISA (IgG). Отримані результати оцінювали як позитивні, проміжні або негативні та інтерпретували згідно з рекомендаціями виробника. Для визначення IgM методом імунного блотингу використано тест-системи EUROLINE Borrelia RN-AT adv. Відповідно до рекомендацій виробника, показник IgM вважали позитивним, проміжним або негативним залежно від комбінацій OspC-антигенів чотирьох видів борелій: OspC Ba (B. afzelii), OspC Bb (B. burgdorferi), OspC Bg (B. garinii), OspC Bsp (B. spielmanii), p39 та VIsE (табл. 1).

Таблиця 1

Критерії оцінювання наявності антитіл класу IgM проти В. burgdorferi

\begin{tabular}{|c|c|c|c|}
\hline \multirow{2}{*}{\multicolumn{2}{|c|}{$\begin{array}{c}\text { Результат за антитілами } \\
1 \text { смуга позитивна }\end{array}$}} & \multicolumn{2}{|c|}{ Смуги специфрічних антигенів: p39, VIsE B } \\
\hline & & Відсутність позитивних & \\
\hline \multirow{3}{*}{$\begin{array}{l}\text { Смуги } \\
\text { ОspC Ba } \\
\text { або } \\
\text { OspC Bb } \\
\text { або } \\
\text { OspC Bg } \\
\text { або } \\
\text { OspC Bsp }\end{array}$} & Смуга антигенів позитивна & Позитивний & Позитивний \\
\hline & $\begin{array}{c}\text { OspC Ва або OspC Bg } \\
\text { слабко позитивні }\end{array}$ & Позитивний & Проміжний \\
\hline & Смуга антигенів негативна & Позитивний & Негативний \\
\hline
\end{tabular}

\section{Результати досліджень та їх обговорення}

Позитивні або проміжні результати серологічного дослідження сироваток крові на наявність специфічних IgM i IgG до комплексу B. burgdorferi s. I. (B. burgdorferi S. S., B. garinii, B. afzelii) за допомогою тесту ELISA (хоча б одного класу антитіл) знайдено в 24 (70,6 \%) із 34 пацієнтів 3 мігруючою еритемою та 11 (78,6 \%) 3 Лаймартритом (табл.2). Отримані нами дані співзвучні з результатами науковців Львівщини, які діагноз ЛБ за допомогою виявлення протиборелійних IgM і (або) IgG підтвердили в 64,7 \% пацієнтів 3 мігруючою еритемою [7].

У 34 пацієнтів I групи позитивні або проміжні результати стосовно специфрічних IgМ були у 19 (55,9\%), IgG - у 12 (35,3 \%) осіб, тоді як серед хворих II групи - лише щодо IgM - у 11 (78,6 \%). Отже, частота виявлення специфрічних IgM в обох групах обстежених була майже однаковою ( $>0,05)$. Специфрічні IgG знаходили лише у пацієнтів I групи ( $>>0,05)$.

Для виявлення специфічних антитіл класу М не лише до В. burgdorferi s. s., B. garinii, B. afzelii, але й до B. spielmanii було використано тести EUROLINE Borrelia RN-AT adv (імуно-блот). Обстежено тих самих 34 хворих
3 мігруючою еритемою та 14 - із Лайм-артритом, яким попередньо вміст специфічних антитіл до комплексу B. burgdorferi s. I. (B. burgdorferi s. S., B. garini, та B. afzelii) визначали за допомогою тесту ELISA. Дані обстеження в мешканців Тернопільщини проведені вперше, вони співпадають із результатами науковців Польщі, які діагностували позитивні антитіла класу М у 71,0% пацієнтів з мігруючою еритемою та 21,0 \% у пацієнтів із Лаймартритом [8].

Порівняно вміст специфічних IgM до комплексу B. burgdorferi s. I. (тест ELISA та EUROLINE Borrelia RNAT adv) у кожній з груп обстежених, зокрема. Встановлено, що негативний результат пошуку специфрічних IgM до комплексу B. burgdorferi s. I. в обох групах був вищим за тестом ELISA порівняно із EUROLINE Borrelia RN-AT $\operatorname{adv}(p<0,05$, табл. 3)

Порівняння частоти діагностики специсрічних антитіл IgM (позитивних і проміжних) до B. burgdorferi s. I. (B. burgdorferi s. s., B. garinii, B. afzelii та B. spielmanii) у 34 пацієнтів 3 мігруючою еритемою, методом ІФА та імуно-блоту, показало, що вона була вища при використанні імуно-блотингу (76,5 \%) порівняно із методом ІФА $(55,9$ \%) ( $<<0,05$, мал. 1) 
Таблиця 2

Частота виявлення антитіл класів IgM i IgG (тест ELISA) у сироватці крові пацієнтів з мігруючою еритемою та Лайм-артритом

\begin{tabular}{|c|c|c|c|c|c|}
\hline \multicolumn{2}{|c|}{ Результат пошуку антитіл до B. burgdorferi } & \multicolumn{2}{|c|}{$\begin{array}{c}\text { I група } \\
(\mathrm{n}=34)\end{array}$} & \multicolumn{2}{|c|}{$\begin{array}{c}\text { II група } \\
(\mathrm{n}=14)\end{array}$} \\
\hline $\lg M$ & $\lg G$ & $\mathrm{n}$ & $\%$ & $\mathrm{n}$ & $\%$ \\
\hline Позитивний & Позитивний & 4 & 11,8 & - & - \\
\hline Позитивний & Негативний & 9 & 26,5 & 6 & 42,9 \\
\hline Проміжний & Позитивний & - & - & - & - \\
\hline Позитивний & Проміжний & 2 & 5,9 & - & - \\
\hline Проміжний & Проміжний & 1 & 2,9 & - & - \\
\hline Негативний & Позитивний & 5 & 14,7 & - & - \\
\hline Проміжний & Негативний & 3 & 8,8 & 5 & 35,7 \\
\hline Негативний & Проміжний & - & - & - & - \\
\hline \multicolumn{2}{|c|}{ Загалом позитивних } & 24 & 70,6 & 11 & 78,6 \\
\hline Негативний & Негативний & 10 & 29,4 & 3 & 21,4 \\
\hline
\end{tabular}

Таблиця 3

Порівняння частоти виявлення антитіл IgM до B. burgdorferi s. І. в сироватці крові пацієнтів з мігруючою еритемою та Лайм-артритом

\begin{tabular}{|c|c|c|c|c|c|c|c|c|}
\hline \multirow{3}{*}{ Результат } & \multicolumn{4}{|c|}{ ELISA } & \multicolumn{4}{|c|}{ EUROLINE Borrelia RN-AT adv } \\
\hline & \multicolumn{2}{|c|}{$\begin{array}{c}\text { I група } \\
(\mathrm{n}=34)\end{array}$} & \multicolumn{2}{|c|}{$\begin{array}{c}\text { II група } \\
(\mathrm{n}=14)\end{array}$} & \multicolumn{2}{|c|}{$\begin{array}{c}\text { I група } \\
(\mathrm{n}=34)\end{array}$} & \multicolumn{2}{|c|}{$\begin{array}{c}\text { II група } \\
(n=14)\end{array}$} \\
\hline & $\mathrm{n}$ & $\%$ & $\mathrm{n}$ & $\%$ & $\mathrm{n}$ & $\%$ & $\mathrm{n}$ & $\%$ \\
\hline Позитивний & 15 & 44,1 & 6 & 42,9 & 20 & 58,8 & 9 & 64,3 \\
\hline Проміжний & 4 & 11,8 & 5 & 35,7 & 6 & 17,7 & 3 & 21,4 \\
\hline Негативний & 15 & $44,1^{*}$ & 3 & $21,4^{*}$ & 8 & 23,5 & 2 & 14,3 \\
\hline
\end{tabular}

Примітка. * - за критерієм X-квадрат, порівняно з показником у межах відповідної групи, різниця достовірна (р<0,05).

Вивчення етіологічної структури гострого ЛБ в 26 пацієнтів з мігруючою еритемою (І група) та 12 - 3 Лаймартритом (II група) встановило, що OspC B. spielmanii знайдено у 24 (92,3 \%) пацієнтів I групи та 12 (100\%) пацієнтів з ІІ. В 11 (78,6 \%) із 14 хворих з гострим Лаймартритом знайдено OspC B. burgdorferi s. S., B. garinii, B. afzelii одночасно (мал. 2).

Слід зазначити, що антитіла до р41 (фрлагеліну, джгутикового, родоспецифрічного антигену з молекуляр- ною масою $41 \mathrm{kDa})$ виявлено у $18(69,2 \%)$ із 26 пацієнтів I групи та 4 (33,3 \%) із 12 - II групи. Антитіла до антигену р39 (по-іншому, Borrelial membrane protein $A(B m p A)$, цитоплазматичний білок молекулярною масою $39 \mathrm{kDa}$ ) наявні у 5 (19,2\%) пацієнтів 3 мігруючою еритемою та $3(25,0 \%)$ - із Лайм-артритами. У складі IgM до VIsE (по-іншому, Variable like segence expressed, рекомбінантний антиген) не виявлено в жодного з обстежених (мал. 3). 


\section{ОРИГІНАЛЬНІ ДОСЛІДЖЕННЯ}

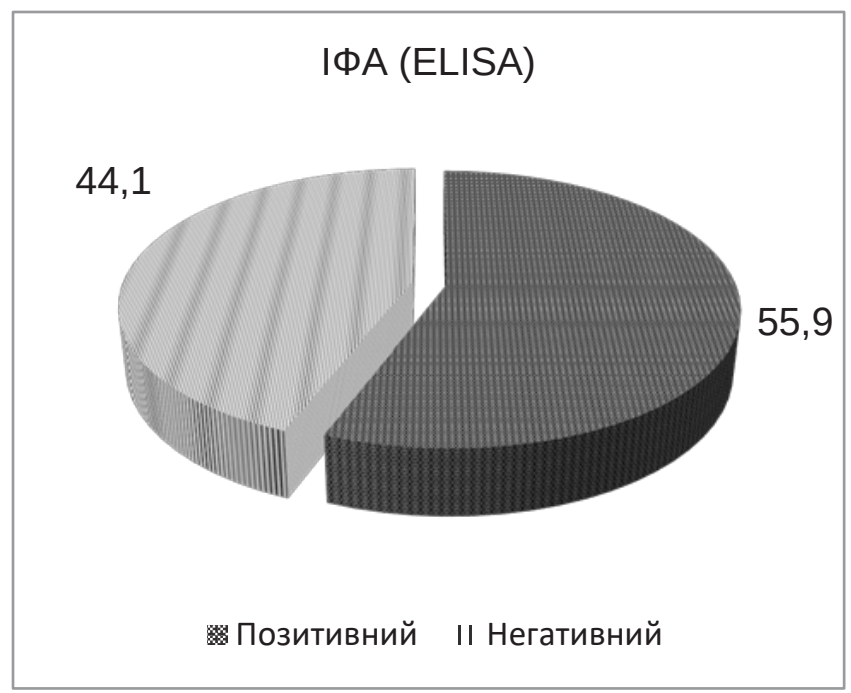

\section{Iмуно-блот (EUROLINE RN-AT adv)}

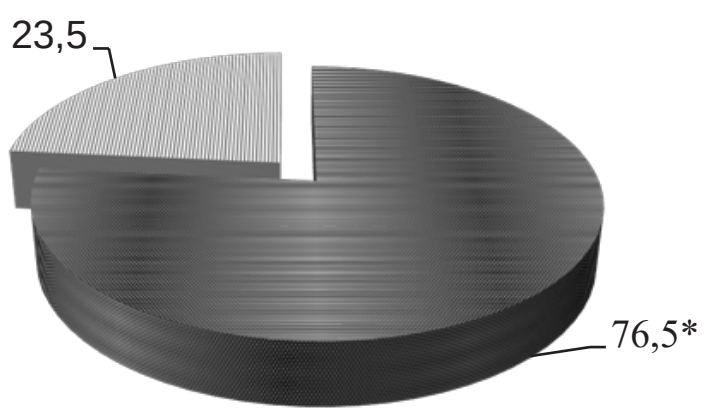

Позитивний II Негативний

Мал. 1. Частота виявлення сумарних антитіл IgM (\%) до B. burgdorferi s. I. (B. burgdorferi s. S., B. garinii, B. afzelii та B. spielmanii) у сироватці крові пацієнтів I групи (тести ELISA та EUROLINE Borrelia RN-AT adv) $\left({ }^{*}-\mathrm{p}<0,05\right)$.

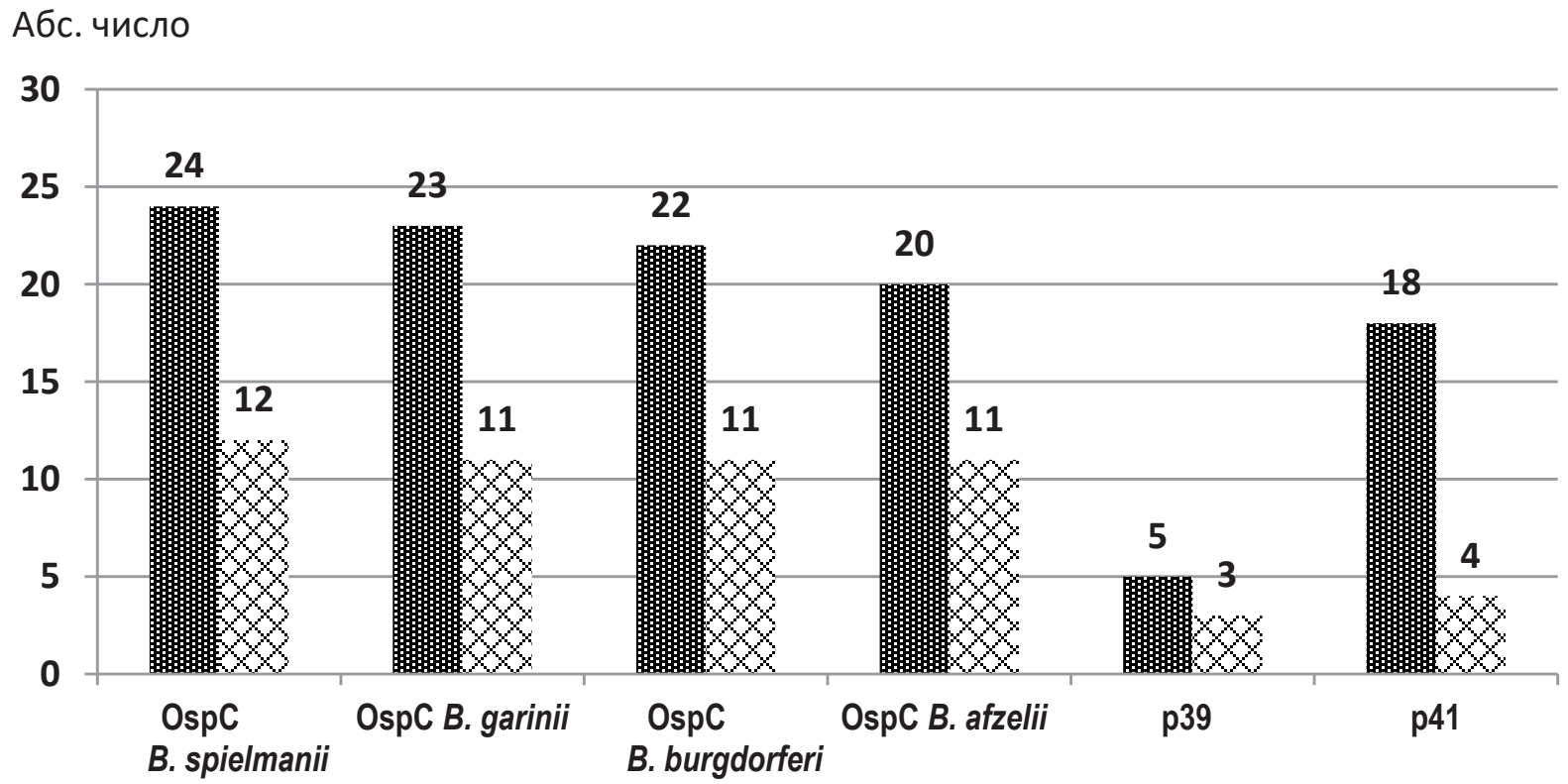

用 Пацієнти з ураженням шкіри (мігруюча еритема), n=26

$\times$ Пацієнти з ураженням опорно-рухової системи, $\mathrm{n}=12$

Мал. 2. Порівняння частоти виявлення специфрічних IgM (позитивні і проміжні) до B. burgdorferi s. I. (B. burgdorferi s. S., B. garinii, B. afzelii та B. spielmanii) у сироватці крові пацієнтів обох груп (тест EUROLINE Borrelia RN-AT adv). 


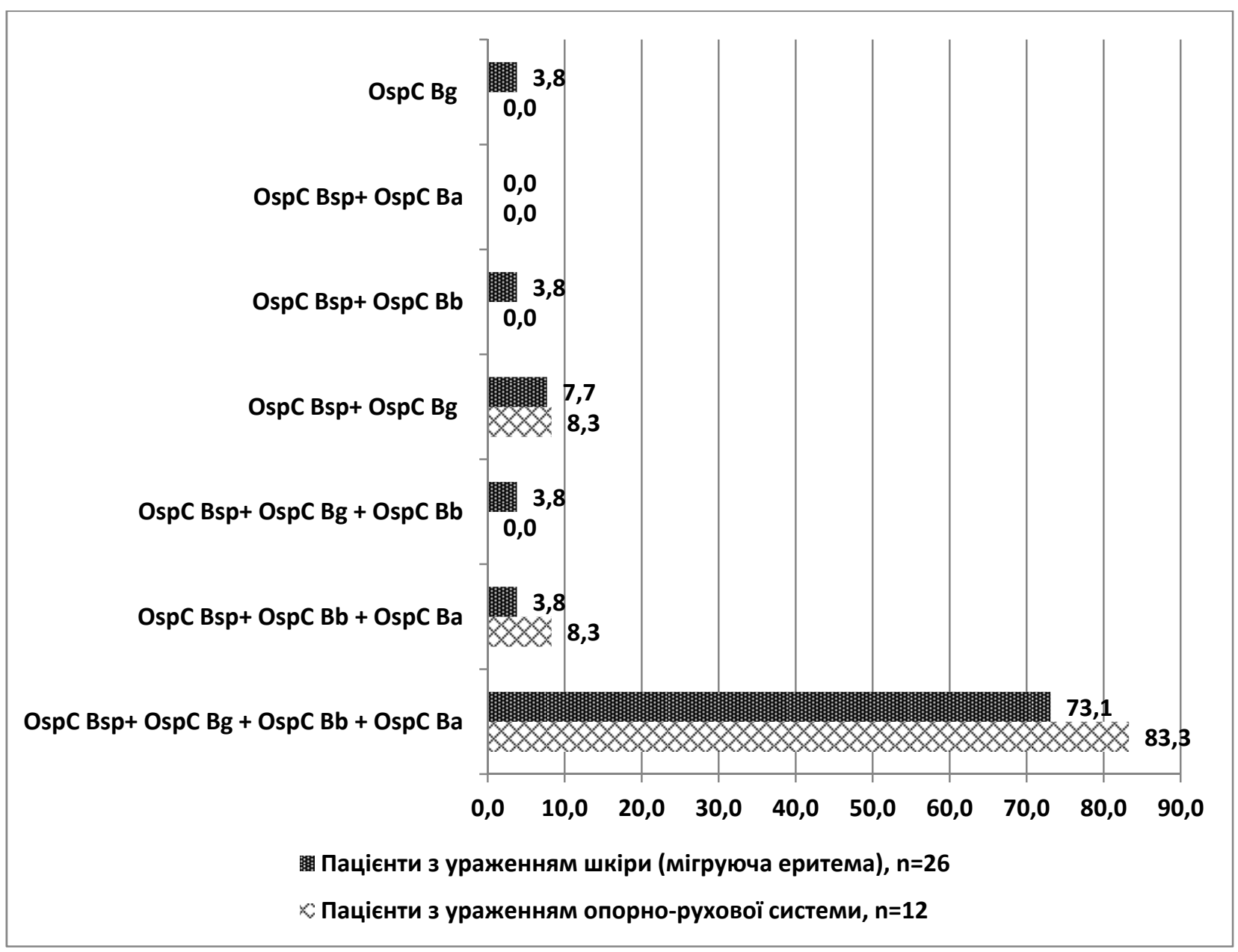

Мал. 3. Комбінація специфічних антитіл IgM (позитивні та проміжні) до антигенів B. burgdorferi s. I. (B. burgdorferi s. S., B. garinii, B. afzelii та B. spielmanii) у сироватці крові пацієнтів обох груп (тест EUROLINE Borrelia RN-AT adv), \%.

Слід зазначити, що поєднання антитіл до поверхневих антигенів усіх 4 збудників (OspC Ba, OspC Bb, OspC $B g$, OspC Bsp) було у $19(73,3 \%)$ із 26 пацієнтів із мігруючою еритемою та в 10 (83,3 \%) із 12 - із Лайм-артритом; комбінацію антитіл до поверхневих антигенів 3 збудників (OspC Ba, OspC Bb, OspC Bsp) мали по одному пацієнту в обох групах. Окрім того, лише по одному пацієнту 3 мігруючою еритемою мали комбінації антитіл до двох (OspC Bb i OspC Bsp) і до трьох антигенів (ОspC $B b$, OspC Bs, OspC Bg), проте без антитіл до поверхневого антигену OspC Ba., тоді як за даними літератури, саме $B$. afzelii відносно частіше притаманна пацієнтам із шкірними проявами ЛБ $[9,10]$.

Отримані нами результати співзвучні з даними польських науковців, які IgM до p41 виявили в сироватці крові 71,5 \% пацієнтів з гострим ЛБ. Проте антитіла до OspC B. spielmanii ними знайдено в 42,3 \% обстежених $[11,12]$, тоді як у проведених нами дослідженнях у 92,3 \% пацієнтів 3 мігруючою еритемою та 100 \% - із гострим Лайм-артритом.

\section{Висновки}

1. При серологічному дослідженні у тесті ELISA антитіла хоча б одного класу IgM i/чи IgG до B. burgdorferi s. I. (B. burgdorferi s. S., B. afzelii та B. garinii, позитивні або проміжні результати) виявлено в 70,6 \% пацієнтів 3 мігруючою еритемою та 78,6 \% - 3 Лайм-артритом.

2. Специфрічні IgG у тесті ELISA було виявлено лише в сироватці крові 35,3 \% пацієнтів з мігруючою еритемою, що може свідчити про імунну пам'ять або хронічний процес.

3. Частота виявлення специфрічних IgM при серологічному дослідженні у тесті ELISA склала 55,9 \% у пацієнтів з мігруючими еритемами та 78,6 \% - 3 Лаймартритом, тоді як методом імуноблоту (EUROLINE Borrelia RN-AT adv) більше - 76,5 та 85,7 \% відповідHO. 
4. Специфрічні IgМ у сироватці хворих з мігруючими еритемами виявлено частіше методом імуноблоту порівняно $з$ тестом ELISA (76,5 проти 55,9 \%).
5. Гуморальну відповідь на поверхневий антиген (OspC) B. spielmanii встановлено в 92,3 \% пацієнтів 3 мігруючою еритемою та 100,0% хворих з гострим Лаймартритом.

\section{Література}

1. Задорожна В.І. Лайм-бореліоз - особливо небезпечна інфекція. Загрози та ризики / В.І. Задорожна, А.О. Руденко, В.Ю. Клюс // Ветеринарна медицина. - 2017. - № 103. - С. 30-32.

2. High-throughput screening of tick-borne pathogens in Europe / M. Lorraine, S. Delannoy, E. Devillers [et al.] // Frontiers in Cellular and Infection Microbiology. - 2014. - Vol. 4. - P. 1-13.

3. Ecology of Borrelia burgdorferi sensu lato in Europe: transmission dynamics in multi-host systems influence of molecular processes and effects of climate change / A. Mannelli, L. Bertolotti, L. Gern, J. Gray // FEMS Microbiol Rev. - 2012. - Vol. 36. - P. 837-861.

4. Ticks and tick-borne diseases in Ireland / A. Zintl, S. Moutailler, P. Stuart [et al.] // Irish Veterinary Journal. - 2017. - Vol 70 (4). P. 1-10.

5. Risk of tick-borne bacterial diseases among forestry workers of Ternopil region / M. Shkilna, M. Andreychyn, M. Korda [et al.] // HPC. - 2017 - Vol. 11 (2). - P. 93-98

6. Туряниця С.М. Динаміка ситуації щодо хвороби Лайма на Закарпатті / С.М. Туряниця, Ю.В. Андрашко, М.М. Сакаль // Клінічна імунологія. Алергологія. Інфектологія. - 2012. - № 1-2 (50-51). - С. 61-64
7. Зінчук О.М. Ураження шкіри на ранній стадії Лайм-бореліозу / О.М. Зінчук // Проблеми екологічної та медичної генетики і клінічної імунології. - 2006. - № 4-5 (73-74). - С. 290-297.

8. Western blot method as a necessary step of serodiagnosis of Lyme disease / J. Noworyta, M. Machcińska, M. Brasse-Rumin, J. Ząbe // Reumatologia. - 2012. - Vol. 50 (5). - P. 397-402.

9. Виноград Н.О. Віддалені наслідки при іксодових кліщових бореліозах / Н.О. Виноград, З.П. Василишин, Л.П. Козак // Сучасні інфекції. - 2009. - № 2. - С. 15-20.

10. Updates on Borrelia burgdorferi sensu lato complex with respect to public health / N. Rudenko, M. Golovchenkova, L. Grubhoffera, J.H. Oliver // Ticks Tick Borne Dis. - 2011. - Vol. 2 (3). - P. 123-128.

11. Stanek G. The expanding Lyme Borrelia complex - clinical significance of genomic species? / G. Stanek, M. Reiter // Clinical Microbiology and Infection. - 2011. - Vol 17 (4). - P. 487-493.

12. Seroprevalence of Lyme disease and genospecies of Borrelia burgdorferi sensu lato in patients diagnosed with borreliosis in the Province of Warmia-Masuria in north-eastern Poland / K. Kubiak, E. Dzika, J. Równiak, M. Dziedziech // Annals of Agricultural and Environmental Medicine. - 2012. - Vol. 19 (2). - P. 203-207.

\section{References}

1. Zadorozhna, V.I., Rudenko, A.O., \& Klius, V.Yu. (2017). Laymborelioz - osoblyvo nebezpechna infektsiia. Zahrozy ta ryzyky [Lyme borreliosis is a particularly dangerous infection. Threats and risks]. Veterynarna medytsyna: Zbirnyk naukovykh prats - Veterinary Medicine: Collection of Scientific Works, 103, 30-32 [In Ukrainian]

2. Lorraine, M., Delannoy, S., Devillers, E., Umhang, G., \& Aspan, A. (2014). High-throughput screening of tick-borne pathogens in Europe. Frontiers in Cellular and Infection Microbiology, (4), 1-13.

3. Mannelli, A., Bertolotti, L., Gern, L., \& Gray, J. (2012). Ecology of Borrelia burgdorferi sensu lato in Europe: transmission dynamics in multi-host systems, influence of molecular processes and effects of climate change. FEMS Microbiol. Rev., 36, 837-861.

4. Zintl, A., Moutailler, S., Stuart, P., Paredis, L., \& Dutraive, J. (2017). Ticks and tick-borne diseases in Ireland. Irish Veterinary Journal, 70 (4), 1-10.

5. Shkilna, M., Andreychyn, M., Korda, M, Klisch, I., \& Rogalskyy, I. (2017). Risk of tick-borne bacterial diseases among forestry workers of Ternopil region. HPC, 11 (2), 93-98.

6. Turianytsia, S.M., Andrashko, Yu.V., \& Sakal, M.M. (2012). Dynamika sytuatsii shchodo khvoroby Laima na Zakarpatti [Dynamics of the situation regarding Lyme disease in Zakarpattia region]. Klinichna imunolohiia. Alerholohiia. Infektolohiia - Clinical Immunology. Allergology. Infectology, 1-2 (50-51), 61-64 [in Ukrainian].
7. Zinchuk, O.M. (2006). Urazhennia shkiry na rannii stadii Laimboreliozu [Skin damages at the early stage of Lyme borreliosis]. Problemy ekolohichnoi ta medychnoi henetyky i klinichnoi imunolohiiProblems of Ecological and Medical Genetics and Clinical Immunology, 4-5 (73-74), 290-297 [in Ukrainian].

8. Noworyta, J., Machcińska, M., Brasse-Rumin, M., \& Ząbe, J. (2012). Western blot method as a necessary step of serodiagnosis of Lyme disease. Reumatologia, 50 (5), 397-402.

9. Vynohrad, N.O., Vasylyshyn, Z.P., \& Kozak, L.P. (2009). Viddaleni naslidky pry iksodovykh klishchovykh boreliozakh [Long-term implications of Ixodes tick's borelliosis]. Suchasni infektsii - Modern Infections, 2, 15-20 [in Ukrainian].

10. Rudenko, N., Golovchenkova, M., Grubhoffera, L., Oliver, J.H. (2011). Updates on Borrelia burgdorferi sensu lato complex with respect to public health. Ticks Tick Borne Dis, 2 (3), 123-128.

11. Stanek, G., \& Reite, M. (2011). The expanding Lyme Borrelia complex - clinical significance of genomic species? Clinical Microbiology and Infection, 17 (4), 487-493.

12. Kubiak, K., Dzika, E., Równiak, J., \& Dziedziech, M. (2012). Seroprevalence of Lyme disease and genospecies of Borrelia burgdorferi sensu lato in patients diagnosed with borreliosis in the Province of Warmia-Masuria in north-eastern Poland. Annals of Agricultural and Environmental Medicine, 19 (2), 203-207. 


\section{ETIOLOGICAL STRUCTURE OF ACUTE LYME BORRELIOSIS BY TYPES OF PATHOGEN}

M.I. Shkilna

I. Horbachevsky Ternopil State Medical University

SUMMARY. The aim of the study was to learn the prevalence of Lyme borreliosis with different species of Borrelia in patients with acute Lyme disease (erythema migrans and Lyme arthritis) in the Ternopil region.

Patients and methods. The present studies were conducted based on 48 patients with acute Lyme disease. The age of tested persons ranged from 19-65 years, who in 2018 were on outpatient and inpatient treatment at the Ternopil Regional Clinical Dermatology Center and the University Hospital; among them 19 (39.6 \%) men and 29 (60.4 \%) women. Patients were divided into two groups: 34 (group I) - patients with erythema migrans (ME) and 14 (group II) - with Lyme arthritis (LA). Diagnosis of Lime borreliosis was confirmed by anamnestic, clinical and serologic findings. A specific diagnosis was established in the presence of specific IgM and (or) IgG in the serum of patients blood of the $B$. burgdorferi complex using ELISA method and IgM were confirmed by immunoblot (EUROLINE Borrelia RN-AT adv).

Results. In 24 (70.6\%) of 34 patients with erythema migrans and 11 (78.6\%) of Lyme-artritis presence of specific antibodies: at least one IgM and /or IgG class to $B$. burgdorferi sensu lato (B. burgdorferisensu stricto, $B$. afzelii and B. garinii) were detected by ELISA tet. Comparison of the frequency of diagnosis of specific antibodies IgM (positive and intermediate) to B. burgdorferi s. I (B. burgdorferi ss, B. garinii, B. afzelii and $B$. spielmanii) in 34 patients with erythema migrans,
ELISA and immunoblot showed that it was higher in immunoblot (76.5\%) compared to $55.9 \%$ of the ELISA $(p<0.05)$. The study of the etiological structure of acute Lyme borreliosis in 26 patients with erythema migrans (group I) and 12 patients with Lyme arthritis (Group II) found that OspC B. spielmanii was found in 24 (92.3\%) patients in Group I and 12 (100\%) of patients in Group II. Conclusions. Specific IgG in the ELISA test was detected only in blood serum of $35.3 \%$ of patients with erythema migrans, which may indicate immune memory or chronic process. The humoral response to the surface antigen (OspC) B. spielmanii was found in $92.3 \%$ of patients with erythema migrans and $100.0 \%$ of patients with acute Lyme arthritis.

Key words: Lyme borreliosis; erythema migrans; Lyme arthritis; Borrelia burgdorferi; Borrelia spielmanii; diagnosis; ELISA; immunoblot.

\section{Відомості про автора:}

Шкільна Марія Іванівна - к. мед. н., доцент кафедри інсрекційних хвороб з епідеміологією, шкірними та венеричними хворобами Тернопільського державного медичного університету ім. І.Я. Горбачевського; e-mail: shkilnami@ tdmu.edu.ua

\section{Information about autor:}

Shkilna Mariya - Candidate of Medicine, Associated Professor of the Department of the Infectious Diseases and Epidemiology, Skin and Venereal Illnesses Department of I. Horbachevsky Ternopil State Medical University; e-mail: shkilnami@tdmu.edu.ua

Конфрлікт інтересів: немає

Author has no conflict of interest to declare.

Отримано 12.12.2018 р. 